\title{
The capacity of personnel in disaster risk management in South African municipalities
}

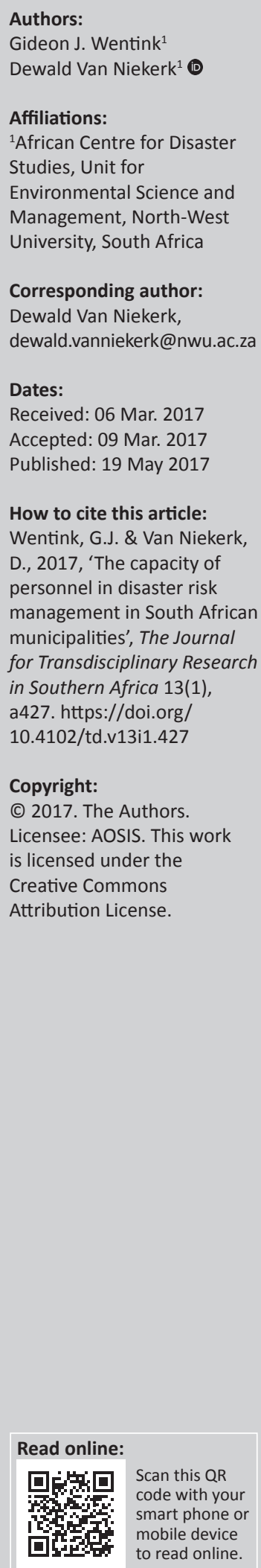

Since 1994, fundamental transformation in South Africa in terms of disaster risk reduction taken place. The transformation process led to the promulgation of the Disaster Management Act (57/2002) (DMA) that introduced a new era of disaster risk management (DRM) in South Africa. The National Disaster Management Framework (NDMF) that followed in 2005 put clear guidelines in place for implementing the DMA and emphasised the importance of the integration and coordination of DRM activities in all spheres of government. To adhere to the requirements of the DMA regarding personnel, certain DRM structures like interdepartmental committees, disaster management centres, disaster management frameworks and disaster management advisory forums must be in place. Since the promulgation of the DMA in 2003, South African municipalities have had ample time to get the structures in place. This article tries to evaluate the degree to which South African municipalities adhere to the requirements of the DMA in terms of personnel. Municipalities were selected per province, and the research is based on a $20 \%$ representative sample of all 279 municipalities in South Africa. A mixed method of research was followed. The result of this research showed a clear lack of implementation in terms of the DMA. A number of disaster management personnel work in other municipal departments, meaning that their attention cannot fully be focused on activities relating to DRM.

\section{Introduction}

It can be argued that disaster risk management (DRM) has become increasingly important on the international agenda in the past decade. Natural hazards like floods, droughts, earthquakes and epidemics have had an increasing impact on human lives (Ford 2010). Other aspects that have an influence on livelihoods are increasing global population, urbanisation, increasing poverty and global environmental change that includes climate change, erosion and deforestation (IISD 2007:1). Practitioners and researchers acknowledge that conditions for vulnerability are created by said underlying factors, leading to insufficient capacity when the possible negative effects of hazards are addressed (IISD 2007:1). Vulnerability may therefore add as much to the scope of disaster risks as the natural hazards themselves. Most experts are of the opinion that it is necessary to take steps to strengthen the sustainable development process and to reach the Millennium Development Goals (MDGs) (Cannon 2007; DFID 2004; IISD 2007). In contrast to this suggestion, Van Riet and Diedericks (2009) noted that DRM in South Africa evolved at a slow pace since the adoption of the Disaster Management Act (DMA) in 2002. A number of municipalities, especially district municipalities, have not succeeded in putting the most basic DRM structures in place. Along with that, there seems to be a high degree of ignorance in terms of the basic principles of DRM within most governmental departments National Disaster Management Centre (NDMC) (NDMC 2010:9; Van Riet \& Diedericks 2009). Van Riet and Diedericks (2009) also found that disaster management centres (DMCs) have inadequate capacity and that lack of personnel, equipment and funding are common problems.

Since the promulgation of the DMA, South African municipalities have had more than 10 years to comply with the legal requirements. The lack of basic DRM structures in South African municipalities, together with the degree of ignorance regarding the basic principles of DRM in governmental departments, is not conducive for DRM in South Africa (Department of Provincial and Local Government 2008; Van Niekerk 2011).

Economic, sustainable, efficient and effective implementing of the National Disaster Management Framework (NDMF) and the strategic priorities, programmes and projects in the DMA are essential to ensure social and economic growth and better service delivery, thereby reducing vulnerability in communities. According to Hoogstad and Kruger (2008) and Van Riet and 
Diedericks (2009:11-12), this strategy is not implemented effectively and efficiently in practice.

This article is based on a study that was based on a DRM status assessment at municipalities in South Africa. The research problem investigated in this article is the current status with regard to the implementation of the DMA in the local sphere of government in South Africa. A particular focus is placed on the capacity (in terms of level of training and number) of personnel.

\section{Disaster risk management in South Africa: A literature review}

For the purpose of this article, a disaster is defined as a progressive or sudden, wide-spread or localised, natural or human-made event that seriously disrupts the functioning of a community causing human, material, economic and environmental losses that exceeds the coping capacity of a community in the use of resources to such a degree that help from outside parties is needed (cf. South Africa 2003; UNISDR 2009). Quarantelli (1992), Perry (2006:12) and Café (2010) added a meaningful contribution by identifying themes within the study area. They are of the opinion that disasters are inherently a social phenomenon and that a disaster is rooted in the social structures of a society and, as such, it reflects the processes of social change. It is from the characteristics of the social structures of a community where the vulnerability to a certain source can be found (Café 2010; Hewitt 2013; Perry 2006:12; Quarantelli 1992).

Since the dawn of a new political era in South Africa, much has changed; one aspect was to make DRM a mainstream activity by drafting legislation and by integrating development initiatives on national, provincial and local levels (Vermaak \& Van Niekerk 2004). Coordination of DRM had to happen by aligning legislation with international standards and best practices, thereby prioritising DRM in South Africa (NDMC \& Reid 2008a:6; Van Niekerk 2010).

Pelling and Holloway (2006:4) identified three phases in the historical development of South African DRM legislation. The first phase (1994-1999) was characterised by policy formation and extended consultation with stakeholders. In 1998, a Green Paper on Disaster Management was compiled (South Africa 1998) and was followed up in 1999 by a White Paper on Disaster Management. This White Paper defined the South African government's DRM policy for the first time (Van Niekerk 2005).

The second phase (1999-2003) ensured that the discussions resulting from the development of the Green and White Papers was converted to a formal status for DRM (Pelling \& Holloway 2006:4). The White Paper formed the basis for the DRM Bill put up for public debate. After the Bill was published, the DMA (53/2002) was promulgated in 2003 (NDMC \& Reid 2008a:4-5; Pelling \& Holloway 2006:4). The DMA was hailed internationally as a good example of national legislation promoting DRM (Pelling \& Holloway 2006:4). By integrating DRM with development initiatives, the DMA also placed statutory responsibility for disaster reduction on each sphere of government and set a mandate for the establishment of DRM centres on national, provincial and local levels (South Africa 2003; NDMC \& Reid 2008a:4-5).

During the third phase (2003-2005), efforts were made to move the establishment of a legal framework to the creation and funding of a national implementation plan (Pelling \& Holloway 2006:4). According to Benson (2009), institutions in the three spheres of government have to apply their development planning so that DRM is an integral part thereof. Chen et al. (2003) and Gopalakrishnan and Okoda (2007) argued the merits of integrating DRM into development planning. Van Niekerk and Coetzee (2012) and Benson (2009) also found that a community-based approach (CBA) is necessary to get vulnerable communities involved in disaster risk reduction.

Disaster risk management has to be based on an effective institutional plan and framework that has to ensure that all segments of the community are involved (Rahman 2002), and communities have to work with governments to ensure that risks are mitigated (Shaw, Matsuoka \& Tsunozaki 2010:10; UNISDR 2010:3). This means that governments have to involve the community in the DRM process to ensure that the community buys into the activities of the process (cf. Kemp 2008:99; Pelling 2007; Pribadi \& Mariany 2007; UNISDR 2004a:4). Governments have to carry the primary responsibility for the well-being of communities by supplying them with a legal and institutional framework for DRM and by defining clear responsibilities and ensuring that various agencies on national, provincial and local levels coordinate their efforts (Briceño 2006:8). Community participation is encouraged in a number of development areas, including DRM (Buckland \& Rahman 1999) and this is also the case in South Africa (2003). In reality, practical guidance and the involvement of communities is limited and local organisations and people are the main role players in DRM (GNDR 2009:3; Mercer et al. 2008:174; Pelling 2011:394; Twigg 2004:104).

It is necessary that a meaningful link is created between the development of a national policy and the use of mechanisms that can convert DRM principles in usable local-driven activities (UNISDR 2004b:189). Such a link can be achieved by ensuring that local governments and communities are encouraged and financed in order to minimise vulnerability and strengthen local capacity (UNISDR 2004b:189). In this regard, existing community-based organisations ought to be strengthened (Forbes-Biggs \& Maartens 2012; Maartens 2011). Mechanisms like the governmental community participation programme (South Africa. Department of Provincial and Local Government 2007), decision-making and resource management ought to be expanded in ways that include all community groups.

Even though governments are responsible for creating conducive environments where people can be empowered to 
reduce the impact of disasters, the community should not be involved in a way where information is trickled down. De Dios (2002:13) confirms this by saying that people are too often left to their own devices thus increasing their vulnerability.

The role of community participation and people's general coping capacity is recognised as one of the key aspects in the study of disaster risk. The creative link between the negative circumstances in which people live and the positive aspects that are often forgotten underlines the importance of the socioeconomic dimensions of risk (UNISDR 2004b:31). Any system of community planning and safety should be integrated in the bigger administrative functions on national, provincial and local disaster planning or related risk reduction strategies. Sustainable community-based disaster mitigation is dependent on a favourable political environment that understands the process of community participation (UNISDR 2004b:178) and institutional structures that empower (Van Niekerk 2006).

\section{Institutional arrangements for disaster risk management in South Africa}

The historical development of DRM in South Africa shows that it shifted from a reactive to a proactive approach, probably because of the existence of insufficient structures and legal frameworks (Van Niekerk 2005:124). Since 1994, the approach to DRM in South Africa has changed with the government's decision to move away from the stance that disasters are unavoidable. For DRM in South Africa to be effective, institutional arrangements that deal with the issue of disaster risk reduction are necessary. After 1994, the government realised the importance of the establishments of such institutional arrangements.

The Green Paper on Disaster Management (South Africa 1998) was the first formal document on disaster management published by the South African government. This Green Paper (1998) identified several challenges that are still relevant today. Some of these challenges that affect the implementation of DRM policies, strategies and plans in South Africa include:

- lack of funds for training and procurement and maintenance of equipment

- lack of significant support from national and provincial government

- different departments have different demarcations for the same operational area

- formal structures or coordinating mechanisms in certain areas are not in place

- lack of commitment from volunteers - volunteers ask for stipends

- lack of training for officials and communities

- the bureaucratic system when other national departments are approached for help

- lack of personnel or funding for full-time personnel

- lack of a proper communication system
- some municipalities do not regard DRM as a priority and as a result have no budget for it.

To address the above challenges, the DMA made provisions for the establishment of DRM structures in all spheres of government (Van Niekerk 2006:95). These DRM structures will be discussed briefly in the next section.

\section{Disaster risk management structures in South Africa}

Aspects like environmental and agricultural issues that are the responsibility of the national government are also a 'simultaneous competence' (jointly exercised by national and provincial bodies) in terms of the South African Constitution $(108 / 1996)$. For this reason, the role of provincial governments in certain fields is well established while others lag behind. According to the Green Paper, the provincial government may choose to appoint or establish their own coordinated structures to ensure an integrated approach to DRM on provincial level. Van Niekerk (2006:107) refers to this by indicating that the structures developed at national level should also be developed at a provincial level in order to ensure continuity in DRM procedures and principles.

Following this, Van Niekerk (2007:242) argued that the local government sphere is the most important for effectively implementing DRM in South Africa. UNISDR (2004b:127) also referred to this by pointing out that municipal structures are positioned to reduce the loss of human lives and financial costs of disasters. The reason is that local governments are more directly linked to important community services. As such, local government should be organised in a way that the issue of DRM is part of the broader development goals. In addition, the appropriate institutional arrangements for DRM should ensure that the local government sphere and personnel working in DRM are capable of implementing strategies, policies, programmes and projects in a way that it contributes to the reduction of vulnerability of households and communities (World Bank 2005). Capacity development for DRM in South Africa, as required by the DMA and the first Key Performance Area (KPA) (dealing with integrated institutional capacity for DRM) will be discussed in the next section.

\section{Capacity development for disaster risk management in South Africa}

For DRM in South Africa to function effectively, capacity development needs to take place. Capacity development implies that projects to strengthen capacities, be it individual, organisational or community capacities, are based on existing capacities that need to be identified and acknowledged. For the purpose of this article, capacity development is defined as 'the process through which individuals, organisations and societies obtain, strengthen and maintain the capabilities to set and achieve their own development objectives over time' (UNDP 2008). As can be seen in section 'Research Methodology and Empirical Findings' of this article, capacity is still lacking in a number of municipalities. 
In designing a project for capacity development for disaster risk reduction, it is crucial to analyse and understand the local context (Eriksson \& Gustafsson 2007), including general social, political, physical, cultural and environmental factors (UNISDR 2004b). It is also essential to understand the relationships and dependencies between individuals, communities and organisations and that a solution that worked in one location will not necessarily succeed in another location. Furthermore, Hagelsteen and Becker (2013) posited that ownership is one of the cornerstones for capacity development, meaning that the primary responsibility for capacity development rests with internal partners (the individual, organisation of community) and that external partners have supportive roles (UNISDR 2005). Hagelsteen and Becker (2014:95) further mentioned that the sustainability of capacity development increases in direct relation to the level of participation and ownership of the internal partners.

Hagelsteen and Burke (2016) identified eight elements for capacity development for disaster risk reduction, being terminology, local context, partnership, ownership, capacity development, roles and responsibilities, a mix (variety) of activities and methods, and monitoring, evaluating and learning. For capacity development to be effective within an organisation or community or for an individual, these eight elements must be taken into account. Internal and external partners need to be on the same page regarding terminology of disaster risk reduction (DRR) and the external partners must understand the basic political and institutional, social and cultural, physical and environmental, and economic setting of the capacity development project. Capacity development projects must be needs driven (i.e. the internal partner must want to develop their capacities) and a capacity assessment needs to be conducted in order to understand risks from hazards and the current capacities that are available for DRR. Both internal and external partners must have a clear understanding as to their roles and responsibilities during the run of the capacity development project and lastly, continuous monitoring and timely evaluation of the actual results of capacity development initiatives must be ensured.

Developing capacities may take a lot of time and should preferably be integrated into development policies and planning (UNISDR 2005). Another drawback of capacity development projects is that they are often too short in duration due to the fact that DRR is still primarily seen as a humanitarian issue and not as a development issue (Hagelsteen \& Becker 2013:11). Van Niekerk and Annandale (2013:173) found in concurrence that adequate time has to be allocated for capacity development. In terms of the DMCs in South African municipalities, capacity development can take place with external partners like institutions of higher learning, foreign development agencies and government institutions.

\section{The political forum for disaster risk management}

To ensure continuity in DRM approaches and principles, structures should be established on provincial level and local level (Van Niekerk 2006:107). To ensure consistency with arrangements on provincial level, arrangements on local level should execute the same responsibilities. The ideal is that an inter-municipal committee is established on local level with the specific goal of DRM that is consistent in goal and structure with the provincial committee (NDMC \& Reid 2008b:9). Alternatively, existing structures that serve the same purpose at local level like the Mayoral Committee and the district interdepartmental forum can be used.

According to Botha et al. (2011), the role of the local municipality in DMA activities is the assembly of a disaster management committee consisting of municipal managers, local businesses and volunteers, among others to:

- establish community partnerships that combine properties of all stakeholders in disaster resistance

- facilitate special training programmes for volunteers in which issues like reduction, prevention, vulnerability assessments and greater awareness of risks and hazards are addressed

- align the disaster management plans of local municipalities with those of district municipalities.

It thus seems clear that personnel working in DRM in municipalities should acquaint themselves with the provisions of the DMA and they should keep abreast of the operations of the political forums at their disposal. The arrangement for the participation of stakeholders and the involvement of technical advice in DRM planning and activities will be discussed next.

\section{The disaster management advisory forum}

According to Twigg (2009:1), the scope, frequency and complexity of disasters can only be addressed by deploying a wide variety of skills and resources in development programmes and DRM planning. DRM initiatives should simultaneously be multidisciplinary partnerships that involve a range of stakeholders. As a result of the wide range of activities required like vulnerability and risk assessments, capacity building, establishment of social and economic infrastructure, and the use of early warning systems, DRM cannot be controlled by a single government department or sub-section (Van Riet \& Diedericks 2009:2; Vermaak \& Van Niekerk 2004:556).

There appears to be general agreement in South Africa that it is important to establish a Provincial Disaster Management Advisory Forum (PDMAF) with the aim of consistency and uniformity in terms of the requirements of the NDMF (NDMC \& Reid 2008b:28; South Africa 2005:34; Van Niekerk 2006:107). Advisory forums should not only be seen as structures for decision-making (Van Riet \& Diedericks 2009:5), and although it has no mandate to enforce management decisions, it can advise relevant government infrastructure regarding DRM-related issues.

The DMA places no obligation on the local sphere of government to establish a municipal disaster management advisory forum (MDMAF) [see Article 51(1)]. In other words, 
the DMA leaves it to the discretion of a metropolitan or district municipality to compile formal structures like MDMAF. The MDMAF should, however, be established to offer interaction between personnel and external stakeholders on the issue of DRM within the local government sphere (South Africa 2005:35). The recommendation by the national education, training and research needs and resource analysis (NETaRNRA) report (National Education, Training and Research Needs and Resource Analysis for Disaster Risk Management in South Africa) is that a MDMAF should be established to offer a platform where everybody that is involved in DRM can be represented. That would be in line with international norms, and Wilkinson (2009:2) and UNISDR (2004b:137) argued that the partnership approach is the most efficient and effective manner to reduce disaster risks. Because DRM is a multi-sector policy domain and crosses sector interests there is a significant need for participation and coordination for all role players of whom personnel form an important part.

In pursuit of the national goal, every province should establish and implement a policy framework for DRM. According to Van Niekerk (2005:142), it should be aimed at the assurance of an integrated and uniform approach to DRM through all provincial governmental institutions, provincial statutory functionaries, NGOs and the private sector (see Article 28 of the DMA) (South Africa 2003:34-35).

A provincial disaster management framework (PDMF) should be in line with the provisions according to Article 28 of the DMA and the NDMF of 2005. This means that the structure of the PDMF should consist of four KPAs and three enablers related to the provincial government sphere. To ensure integration and coordination of DRM activities in the provincial governmental sphere the national governmental sphere, in accordance with the DMA and the NDMF, should put mechanisms in place for the integrated implementation of DRM policy.

\section{The disaster management centre}

The establishment of a DMC is required by Article 43 of the DMA. Each metropolitan and district municipality must have a district disaster management centre (DDMC) in their area of authority (South Africa 2003:51). The key responsibility of a DDMC is to provide support to the relevant PDMC. This includes ensuring the implementation of the local disaster management policy and that the goals and priorities of provincial and national disaster management is attainable.

After consultation with local municipalities, a municipal disaster management centre (MDMC) should be established [see Article 43(2)(a)] and operated jointly by the district and local municipalities [see Article 43(2)(c)] (South Africa 2003:51). MDMCs carry the responsibility of ensuring that the appropriate capacity for DRM, which includes personnel issues, for the implementation of the DMA is established (Van Niekerk 2005:148). MDMCs should also ensure that institutional arrangements are in line with those on provincial and national levels.
In terms of Article $44(\mathrm{a}-\mathrm{j})$ of the DMA, an MDMC should specialise in problems relating to disasters and DRM in their municipal area. They should also promote an integrated and coordinated approach to DRM in the municipal area with the focus on prevention and mitigation (South Africa 2003:51). Furthermore, an MDMC should store and provide information on disasters and disaster management relating to their municipal area. An MDMC should make recommendations on and try to provide funding for DRM as well as promote recruitment, training and participation of volunteers. They should also promote formal and informal initiatives that encourage risk avoiding behaviour in state organs, the private sector, NGOs, communities, households and individuals in the municipal area. To perform all these tasks, an MDMC should have enough personnel with proper knowledge of DRM.

The municipality can act as an advisory and consultative body on issues concerning disasters and DRM in the municipal area. The MDMC may also make recommendations to any relevant organ of state of statutory functionary regarding draft legislation concerning the DMA, NDMF or any other disaster management issue that could influence South Africa (2003:52).

An MDMC as proposed by Article 51 of the DMA is a structure in which metropolitan or district municipality and the relevant role players consult each other and coordinate their DRM activities. A number of studies (Botha et al. 2011; South Africa 2005:35; Van Niekerk 2007:247) question the feasibility of the implementation of DRM activities in the local sphere of government where an MDMC does not exist. Van Niekerk (2005:149) is therefore of the opinion that it is necessary for the local government sphere to establish such a structure. In the case where local governments choose not to establish an MDMC it is necessary to use alternative structures. Furthermore, Article 51 of the DMA proposes the composition of an MDMC.

\section{The Interdepartmental Disaster Management Committee}

According to NDMC and Reid (2008b:26), the biggest challenge in the implementation of the DMA and the NDMF is to effect integrated and holistic planning and approaches in the departmental structures of the government. To bridge thesechallenges on alocallevel, a Municipal Interdepartmental Disaster Management Committee (MIDMC) may be established by all municipal departments and public entities. The MIDMC provides the structure in which different municipal departments can coordinate and integrate their activities regarding DRM and DRR plans and strategies (Van Niekerk 2007:246).

Furthermore, the purpose of an MIDMC is to facilitate coordinated planning by providing a forum for cooperation on joint cross-departmental plans and programmes aimed at DRM and the integration thereof into development planning. It also acts in a supportive way regarding DDMC and assists with supervision of the preparation, coordination, monitoring 
and review of DRM plans and the integration thereof into the Integrated Development Planning processes. In the case where a municipality decided not to establish these structures, appropriate alternative existing structures need to be identified to ensure that the principles of cooperative governance and community participation are applied in the context of the DMA in accordance with the NDMF. In addition, municipalities should establish their own disaster management committees that will ensure the establishment of DRM fora in their municipal wards takes place.

From the above discussion, the critical importance for MDMCs to have an appointed head specifically tasked with promoting DRM related activities is clear. When the functions and levels of responsibility of the appointed head and other personnel are reviewed, it is necessary that the personnel should be knowledgeable in the discipline they find themselves in. This expertise should be based on the KPAs and the enablers explained in the NDMF. With the expertise in mind, this study will aim to determine whether there are sufficient personnel working in DRM in South African municipalities and whether the personnel have the appropriate knowledge to effectively perform their duties.

\section{Research methodology and empirical findings}

According to Sale et al. (2002:46), a mixed method of research is advantageous because qualitative and quantitative research methods have the common goal of generating knowledge for the sake of practical knowledge. This combination offers the researcher the freedom to analyse the data from different perspectives, adding to the credibility of the study. The quantitative analysis of this study was done within the framework provided for by the qualitative analysis. This results in the quantitative results being rich in context without being only statistical in character.

The design of the empirical study consists of a review of the relevant literature and regulations, telephonic interviews, semi-structured interviews and questionnaires that were disseminated via email, mail and fax. For the postal and faxed pieces, a questionnaire was compiled. In order to obtain information regarding the status of disaster management in all municipalities, the questionnaires were sent to officials in selected MDMCs (metropolitan and district), local municipalities and representatives of municipal departments in South Africa.

The nature and extent of this research relied on the full involvement of the target population. Because of time constraints, the research was based on a representative sample of the total population. A simple random sample in which every element of the population gets the exact same chance of being drawn for the sample was used. In this case, the involvement of all provinces was ensured.

Data gathering began after the target population was identified. The total population consisted of 6 metropolitans,
46 districts and 231 local municipalities in South Africa. From the total population, a $20 \%$ representative sample was identified. The sample thus consisted of 6 metropolitans, 17 districts and 55 local municipalities (as illustrated in Table 1). Table 2 gives an indication of how the sample is spread among South African provinces.

\section{Semi-structured interviews}

A semi-structured interview allows for detailed answers from the interviewee since the interviewer can ask follow-up questions if necessary (Greeff 2007). This type of interview is used when the personal opinions or perceptions of the interviewee is required (Greeff 2007). Even though questions are prepared, the conversation should flow naturally. Questions should also be asked in a way that encourages thorough and detailed answers (Richards \& Morse 2007).

Semi-structured interviews were held with representatives from the Department for Cooperative Governance and Traditional Affairs (Cogta) and the South African Local Government Association (Salga) on a national level.

\section{Telephonic interviews}

In the case where telephonic interviews were held, the interviewer asked questions from a predetermined questionnaire and wrote down the answers of the interviewee. Telephonic interviews were held with the members of the executive committees (MECs) of three provinces and 17 councillors of 9 provinces in an effort to determine the political supervision and oversight of DRM policies and strategies. Each of the 20 respondents were responsible for DRM in their various government domains.

\section{Questionnaires}

The questionnaire that was used in this study consisted of a composition of closed (mainly Likert Scale) and open ended (where a motivation of a preceding Likert Scale question was asked) questions. The questions were divided

TABLE 1: Breakdown of sample.

\begin{tabular}{lccc}
\hline Variable & Local & Metro & District \\
\hline Total population & $\mathbf{2 3 1}$ & 6 & 46 \\
Sample & 55 & 6 & 17 \\
\hline Total respondents & $\mathbf{3 6}$ & $\mathbf{5}$ & $\mathbf{1 2}$ \\
\hline
\end{tabular}

TABLE 2: Simple random sample per province per municipality type.

\begin{tabular}{lccccc}
\hline Province & District & Metro & Local & $\begin{array}{c}\text { Sample } \\
\text { percentage }\end{array}$ & $\begin{array}{c}\text { Sample } \\
\text { count }\end{array}$ \\
\hline Eastern Cape & 3 & 1 & 7 & 14.10 & 11 \\
Free State & 2 & 0 & 8 & 12.82 & 10 \\
Gauteng & 1 & 3 & 2 & 7.69 & 6 \\
KwaZulu-Natal & 3 & 1 & 11 & 19.23 & 15 \\
Limpopo & 2 & 0 & 6 & 10.26 & 8 \\
Mpumalanga & 2 & 0 & 4 & 7.69 & 6 \\
Northern Cape & 1 & 0 & 5 & 7.69 & 6 \\
North West & 2 & 0 & 7 & 11.55 & 9 \\
Western Cape & 1 & 1 & 5 & 8.97 & 7 \\
\hline Total & $\mathbf{1 7}$ & $\mathbf{6}$ & $\mathbf{5 5}$ & $\mathbf{1 0 0 . 0 0}$ & $\mathbf{7 8}$ \\
\hline
\end{tabular}


into subdivisions (biographical information, institutional arrangement, implementation of legal frameworks, roles and responsibilities, and financial obligations) so that the different sections could be easily distinguishable.

\section{Empirical findings and discussion}

For DRM to be carried out as a legal mandate, it requires not only physical resources but also sufficient and well-trained personnel. The next section discusses the various issues regarding personnel and their level of involvement and training as it relates to local government in South Africa.

According to the collected data, 27.3\% of MDMCs employ more than 10 people and $54.6 \%$ of respondents have between 1 and 10 employees. As can be expected, metropolitan municipalities, and to a certain extent some district municipalities, had more employees, partly because said municipalities are in most cases much bigger in an administrative sense than local municipalities, but also because those municipalities have the financial ability to employ more staff members. This means that there are many cases where DMCs function with a small number of people; this can negatively influence their ability to fulfil their duties. From the collected data, it was found that $73 \%$ of respondents felt that not enough staff were working in MDMCs to deliver an adequate service.

In addition, in most centres there is a significant shortage of volunteers where $69.4 \%$ of centres have no volunteers and only $27.7 \%$ have more than 10 volunteers. Furthermore, $65.8 \%$ of DMCs operate without temporary staff. A shortage in support staff causes problems with the implementation of DRM activities and the daily functioning of centres. The presence of more support staff and volunteers can offer assistance in the performing of duties, especially at times of emergencies where manpower is crucial.

Qualifications of personnel range between MDMCs having two or fewer staff members with professional training (41.2\%) and more than five with professional (tertiary) training $(41.2 \%)$ (see Figure 1). There is an inconsistency in capacity regarding disaster management staff. It seems that greater emphasis should be placed on training and capacity building

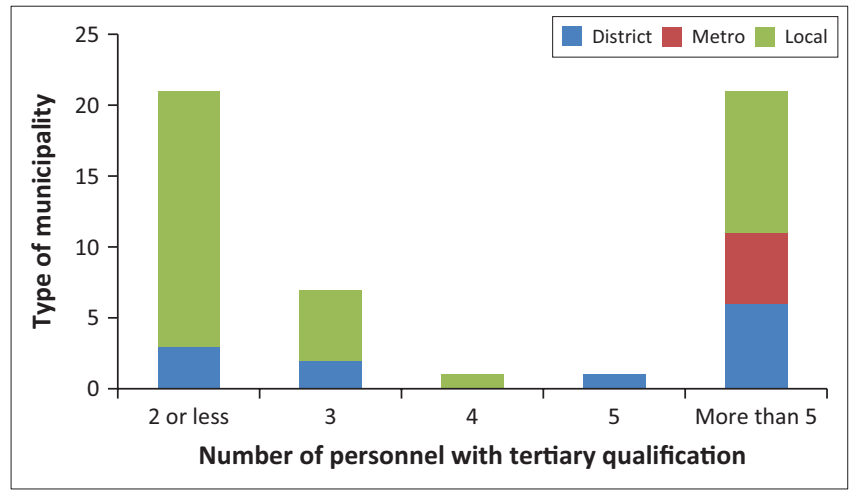

FIGURE 1: Personnel in disaster management centres with tertiary qualifications per type of municipality. to try and bridge this gap in training. A small majority of respondents at local government level (58.5\%) indicated that their personnel is not adequately trained. On provincial level all respondents felt that training is lacking and that disaster management duties are neglected because of this.

In compliance with Articles 15 and 20(2) of the DMA, there is a recognised need for assurance of education, research and training in all fields relating to DRM. In February 2010, a NETaRNRA was done by the NDMC (2010) reflecting the need for better training and capacity development among employees in the field of DRM. In NETaRNRA, $41 \%$ of the respondents indicated that they could perform tasks that they chose themselves. 19\% indicated that they need help completing tasks that they chose themselves and the remaining $40 \%$ said that they need training to allow them to perform tasks that they chose themselves (NDMC 2010).

In reaction to this survey, respondents from local governments indicated a lack of skills in areas like development of contingency plans, disaster risk assessments, and disaster and incident management and assessment. Table 3 gives an indication of the skills that respondents in this study identified as important for representatives of local government. Of special interest is the need for training in the mentioned areas that are compatible with national standards like the South African Qualification Authority and the National Curriculum Framework. The importance of standardising and compatibility was also highlighted in the NETaRNRA report (NDMC 2010).

Within the DRM structure, it is also clear that staff members are often responsible for multiple tasks like those associated with DRM as well as the duties that fall in the sphere of

\begin{tabular}{|c|c|}
\hline Area & Skill shortage \\
\hline \multirow[t]{17}{*}{ Emergency reaction and DRM topics } & Professional firefighting skills \\
\hline & Victim management skills \\
\hline & Emergency management skills \\
\hline & $\begin{array}{l}\text { Incident management training (e.g. } \\
\text { xenophobic violence and disease outbreak) }\end{array}$ \\
\hline & Incident assessment \\
\hline & Radio communication \\
\hline & $\begin{array}{l}\text { Disaster management (general and } \\
\text { introductory) }\end{array}$ \\
\hline & Contingency planning development \\
\hline & Disaster risk assessment \\
\hline & $\begin{array}{l}\text { Programmes for the training of communities } \\
\text { and leaders }\end{array}$ \\
\hline & Life safety education \\
\hline & Safety planning at stage events \\
\hline & $\begin{array}{l}\text { How to conduct planning and advocacy } \\
\text { campaigns }\end{array}$ \\
\hline & $\begin{array}{l}\text { Disaster operations centre principles and } \\
\text { procedures }\end{array}$ \\
\hline & Usage of GIS \\
\hline & Linkage between disaster risk and IDP \\
\hline & Post disaster assessment \\
\hline \multirow[t]{2}{*}{ Administrative topics } & Writing of reports \\
\hline & Project management \\
\hline
\end{tabular}

DRM, disaster risk management; GIS, geographic information systems; IDP, Integrated Development Plan. 
emergency services. Cases arise where DRM staff and other officials share responsibilities in areas like fire services, traffic management, public safety, technical services, marketing and contingency planning. Division of time between multiple responsibilities can lead to inadequate performing of duties. It places unfair pressure on available time and resources to meet the disaster management needs in the municipality. According to South Africa (2005), each national organ of state must appoint an individual that can act as focus point for DRM and that can represent the organ at the National Disaster Management Advisory Forum. This evidence discloses and explains the versatile nature of DRM from which the interdisciplinary skills are drawn. This is especially the case in terms of emergency management and public safety.

According to the findings, personnel that work in external sectors are often involved in DRM. People working in the fields of firefighting, public safety and traffic services, parks and roads, strategic and electrical services, crisis control, corporate services and administration are also recruited for work that relates to DRM. This can be advantageous since different and diverse skills are presented which can help to ensure that interdependent issues are addressed and recognised in DRM. Multisectoral involvement is highlighted and encouraged through leading international frameworks like the Hyogo Framework for Action (HFA), The Sendai Framework for Disaster Risk Reduction, the African Regional Strategy for DRR and the DRR strategy of the Southern African Development Community. There is, however, an inherent need for research on the potential for funding of independent positions for disaster managers so that these managers can focus solely on tasks relating to DRR. This allows the unbiased cooperation and coordination with external stakeholders to ensure public safety through reducing risks.

From Figure 2 it can be interpreted that only municipalities in Gauteng and to a lesser extent the North West, Eastern and Western Cape take the issue of personnel seriously. Concerning municipalities in KwaZulu-Natal, Limpopo, Mpumalanga, the Northern Cape and the Free State, things do not look as good, especially in the Free State where municipalities have on average only two staff members in DRM.

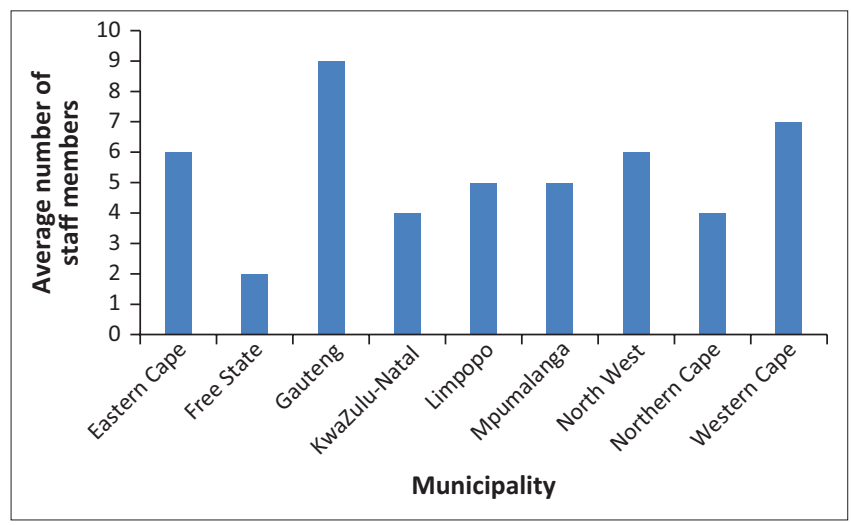

FIGURE 2: Average number of staff members (full time and temporary) per municipality per province (as per data collected).

Regarding staff training the situation does not get better. Municipalities were asked how many staff members received professional training (tertiary education) in DRM or related areas like firefighting or incident management. Figure 3 shows that all municipalities in Gauteng had five or more staff members with professional training and that municipalities in the Northern Cape had two or less professionally trained staff members. One must also note that Gauteng is the smallest province and is home to nearly 10 times more people than in the Northern Cape which is the biggest province. It is also mentionable that more than $50 \%$ of municipalities in Limpopo and the Eastern Cape have five or more professionally trained staff members.

In Table 4, the average population density (of the sample population) per province per municipality is shown. From this table, in conjunction with Figures 2 and 3, the deduction can be made that municipalities in provinces with more money (like Gauteng and the Western Cape) naturally have better trained personnel; what is surprising, however, is that 'poor' municipalities like Limpopo and the North West have a high number of personnel in disaster management with tertiary education in DRM or a relevant area, in relation to the number of people living in the municipalities and the size of those municipalities. The Eastern Cape is another 'poor' province with a good ratio between trained personnel and the population density. In this instance, however, one must keep in mind that a metropolitan municipality forms part of the statistics for the Eastern Cape, which could lead to a misconception of the real situation.

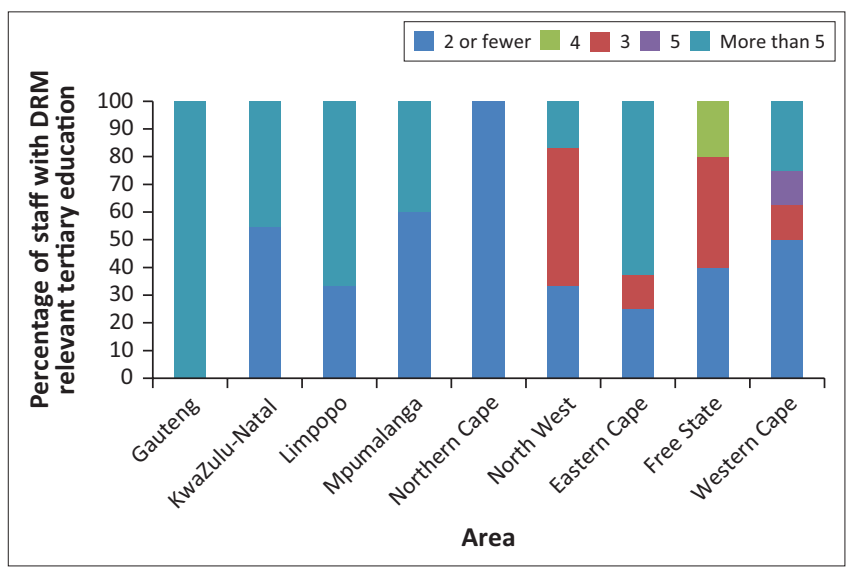

FIGURE 3: Percentage of staff members per municipality that received tertiary education in disaster risk management or relevant area.

TABLE 4: Average population density per province per municipality.

\begin{tabular}{llll}
\hline Province & Metro & District & Local \\
\hline Eastern Cape & $590 / \mathrm{km}^{2}$ & $37 / \mathrm{km}^{2}$ & $17 / \mathrm{km}^{2}$ \\
Free State & N/A & $24 / \mathrm{km}^{2}$ & $52 / \mathrm{km}^{2}$ \\
Gauteng & $1590 / \mathrm{km}^{2}$ & $200 / \mathrm{km}^{2}$ & $\mathrm{~N} / \mathrm{A}$ \\
KwaZulu-Natal & N/A & $126 / \mathrm{km}^{2}$ & $131 / \mathrm{km}^{2}$ \\
Limpopo & N/A & N $/ \mathrm{A}$ & $10 / \mathrm{km}^{2}$ \\
Mpumalanga & N/A & N/A & $88 / \mathrm{km}^{2}$ \\
Northern Cape & N/A & N/A & $2 / \mathrm{km}^{2}$ \\
North West & N/A & $65 / \mathrm{km}^{2}$ & $73 / \mathrm{km}^{2}$ \\
Western Cape & 1530/km & $25 / \mathrm{km}^{2}$ & $38 / \mathrm{km}^{2}$ \\
\hline
\end{tabular}




\section{Conclusion}

Although the municipalities in this study predominantly have the necessary structures in place, it seems that the metropolitan municipalities (especially in Gauteng and the Western Cape) stand out in terms of trained staff members. All the metropolitan municipalities that formed part of the study indicated more than five staff members with professional training in DRM or related fields.

It is also problematic that a number of staff members that work in DRM are also involved in other departments. This leads to their attention being split between DRM related activities and what they need to focus on elsewhere. When a staff member works in two departments, attention is inevitably divided to such a degree that work in either department is neglected.

Municipalities where the DMCs don't function as they should because of personnel training, numbers etc. should make a concerted effort to appoint people and to have staff trained. A way in which this gap can be bridged is for municipalities to budget for the important function of DRM and to apply the designated funds in such a way that staff are not only trained but also that the community where money is spent is empowered regarding DRR. Furthermore, municipalities should be exhorted to adhere to the DMA where it speaks to personnel and that DMCs in municipalities appoint a head at the centre with no other responsibilities than that of disaster management within a specific municipality.

\section{Acknowledgements Competing interests}

The authors declare that they have no financial or personal relationships which may have inappropriately influenced them in writing this article.

\section{Authors' contributions}

D.v.N. conceptualised the article, proofread and made adjustments. G.J.W. compiled the article from his master's thesis.

\section{References}

Benson, C., 2009, Mainstreaming disaster risk reduction into development: Challenges and experiences in the Philippines, ProVention Consortium, Genève, $56 \mathrm{p}$.

Botha, D., Van Niekerk, D., Wentink, G.J., et al., 2011, Disaster risk management status assessment at municipalities in South Africa, report presented to the South African Local Government Association, NWU, Potchefstroom, p. 108.

Briceño, S., 2006, 'Vision without action is a daydream, but action without vision is a nightmare - A global framework for reducing risk', in J. Griffiths \& T. Ingleton (eds.), Real risk, pp. 8-13, Tudor Rose, London.

Buckland, J. \& Rahman, M., 1999, 'Community-based disaster management during the 1997 Red River Flood in Canada', Disasters 23(2), 174-191. https://doi org/10.1111/1467-7717.00112

Café, D.P. 2010, 'The social construction of disasters: Typhoon Ondoy in the context of Sagrada Familia and Inquirer.net', paper presented at the 4th Asian Urban Sociological Association International Conference, Legazpi, Philippines, 6-10 September.

Cannon, T., 2007, Integrating disaster risk reduction into the Millennium Development Goals: Review of activities up to the present, viewed 21 November 2011, from http://www.unisdr.org/files/766_Desk_Review_Report_MDGs_HFA_Oct07_ ActionAid[1].pdf
Chen, K., Blong, R. \& Jacobson, C., 2003, 'Towards an integrated approach to natural hazards risk assessment using GIS: With reference to bushfires', Environmental Management 31(4), 546-560. https://doi.org/10.1007/s00267-002-2747-y

De Dios, H.B., 2002, Participatory capacities and vulnerabilities assessment: Finding the link between disasters and development, Oxfam GB, Quezon City, $78 \mathrm{p}$.

Department for International Development (DFID), 2004, Disaster risk reduction A development concern. A scoping study on links between disaster risk reduction, poverty and development, Norwich: Overseas Development Group, 65 p, viewed 21 November 2011, from http://www.preventionweb.net/files/1070 drrscopingstudy.pdf

Eriksson, O. \& Gustafsson, M., 2007, Disaster management capacity from a national perspective, viewed 15 February 2016, from http://lup.lub.lu.se/student-papers/ record/1689006

Forbes-Biggs, K. \& Maartens, Y., 2012, 'Adolescent girls at risk: The GIRRL program as capacity-building initiative in South Africa', Children, Youth and Environments 22(2), 234-248. https://doi.org/10.7721/chilyoutenvi.22.2.0234

Ford, M., 2010, Are human actions making natural disasters more destructive?, viewed 15 August 2013, from http://edition.cnn.com/2010/WORLD/asiapcf/09/23/eco. flood.pakistan/index.html

Global Network of Civil Society Organisations for Disaster Reduction (GNDR), 2009, Clouds but little rain... Views from the frontline: A local perspective of progress Clouds but little rain... Views from the frontline: A local perspective of progress
towards implementation of the Hyogo Framework for Action, viewed 25 June 2012 , towards implementation of the Hyogo Framework for Action, viewed 25 June 2012,
from http://www.preventionweb.net/files/10129_VFLsummaryreport0609.pdf

Gopalakrishnan, C. \& Okoda, N., 2007, 'Designing new institutions for implementing integrated disaster risk management: Key elements and future directions', integrated disaster risk management: Key elements and future directions',
Disasters 31(4), 353-372. https://doi.org/10.1111/j.1467-7717.2007.01013.x

Greeff, M., 2007, 'Information collection: Interviewing', in A.S. De Vos, H. Strydom, C.B. Fouché \& C.S.L. Delport (eds.), Research at grass roots: For the social sciences and human service professions, pp. 341-375, Van Schaik, Pretoria.

Hagelsteen, M. \& Becker, P., 2013, 'Challenging disparities in capacity development for disaster risk reduction', International Journal of Disaster Risk Reduction 3, 4-13. https://doi.org/10.1016/j.ijdrr.2012.11.001

Hagelsteen, M. \& Becker, P., 2014, 'Forwarding a challenging task: Seven elements for capacity development for disaster risk reduction', Planet@risk 2(2), 94-97.

Hagelsteen, M. \& Burke, J., 2016, 'Practical aspects of capacity development in the context of disaster risk reduction', International Journal of Disaster Risk Reduction 16, 43-52. https://doi.org/10.1016/j.ijdrr.2016.01.010

Hewitt, K., 2013, 'Disasters in "development" contexts: Contradictions and options for a preventative approach', Jàmbá: Journal of Disaster Risk Studies 5(2), viewed 31 October 2013, from http://www.jamba.org.za/index.php/jamba/ article/view/91

Hoogstad, W. \& Kruger, C., 2008, The link between development planning and disaster risk management in selected municipalities, ACDS Research Report, ACDS, Potchefstroom, $30 \mathrm{p}$, viewed 24 March 2011, from http://acds.co.za/uploads/ research_reports/drm_idp_ndmc.pdf

International Institute for Sustainable Development (IISD), 2007, 'A brief history of UN disaster risk reduction', Global Platform for Disaster Risk Reduction Bulletin 141(1), 1-12, viewed 28 March 2012, from http://www.iisd.ca/download/pdf/sd/ $141(1), 1-12$, viewed 28
ymbvol141num1e.pdf

Kemp, R.B., 2008, 'Public participatory GIS in community-based disaster risk reduction', triplec 6(2), 88-104.

Maartens, Y., 2011, 'Development communication in disaster risk reduction: The G.I.R.R.L. (Girls in Risk Reduction Leadership) Project', unpublished MA dissertation, North-West University.

Mercer, J., Kelman, I., Lloyd, K. \& Suchet-Pearson, S., 2008, 'Reflections on use of participatory research for disaster risk reduction', Area 40(2), 172-183. https:// doi.org/10.1111/j.1475-4762.2008.00797.x

National Disaster Management Centre (NDMC), 2010, National education, training and research needs and resources analysis (NETaRNRA) - Consolidated Report viewed 18 April 2011, from http://www.ndmc.gov.za/Documents/NETaRNRAReport/ tabid/295/ctl/ViewDocument/mid/678/ItemID/143/Default.aspx

National Disaster Management Centre (NDMC) \& Reid, P.M., 2008a, South African disaster risk management handbook series (Metropolitan Municipalities): Handbook 1 - Introducing the South African disaster risk management handbook series: Scoping the implementation process, NDMC, Pretoria, $34 \mathrm{p}$.

National Disaster Management Centre (NDMC) \& Reid, P.M., 2008b, South African disaster risk management handbook series (District Municipalities): Handbook 2 Establishing foundational institutional arrangements for disaster risk management, NDMC, Pretoria, $46 \mathrm{p}$.

Pelling, M., 2007, 'Learning from others: The scope and challenges for participatory disaster risk assessment', Disasters 31(4), 373-385. https://doi.org/10.1111/ j.1467-7717.2007.01014.x

Pelling, M., 2011, 'Urban governance and disaster risk reduction in the Caribbean: The experiences of Oxfam GB', Environment and Urbanization 23(2), 383-400. https:// experiences of Oxfam GB', Environment
doi.org/10.1177/0956247811410012

Pelling, M. \& Holloway, A., 2006, 'Legislation for mainstreaming disaster risk reduction', Tearfund, Teddington, $32 \mathrm{p}$.

Perry, R.W., 2006, 'What is a disaster?', in H. Rodríguez, E.L. Quarantelli \& R.R. Dynes (eds.), Handbook of disaster research, pp. 1-15, Springer, New York.

Pribadi, K.S. \& Mariany, A., 2007, Implementing community-based disaster risk reduction in Indonesia: The role of research institutions and religious-based organizations, report from CDM-ITB, UNDP, New York.

Quarantelli, E.L., 1992, The importance of thinking of disasters as social phenomena, DRC Preliminary Paper \#184, University of Delaware, Newark, DE. 
Rahman, H., 2002, 'Community based disaster information management system: Perspective Bangladesh', paper presented at the Regional Workshop on Best Practices in Disaster Mitigation: Lessons learned from the Asian Urban Disaster Mitigation Program, Bali, Indonesia, 24-26 September.

Richards, L. \& Morse, J.M., 2007, Readme first for a user's guide to qualitative methods, Sage, Thousand Oaks, CA.

Sale, J.E.M., Lohfeld, L.H. \& Brazil, K., 2002, 'Revisiting the quantitative-qualitative debate: Implications for mixed-methods research', Quality and Quantity 36(1) 43-53. https://doi.org/10.1023/A:1014301607592

Shaw, R., Matsuoka, Y. \& Tsunozaki, E., 2010, A guide for implementing the Hyogo Framework for Action by local stakeholders: Consultation version, viewed 08 March 2011, from http://www.preventionweb.net/files/13101_ImplementingtheHFA.pdf

South Africa, 1998, Green Paper on Disaster Management, Government Printer, Pretoria.

South Africa, 2003, Disaster Management Act 57 of 2002, Government Printer, Pretoria.

South Africa, 2005, National disaster management framework, Government Printer, Pretoria.

South Africa. Department of Provincial and Local Government, 2007, National policy framework for public participation, viewed 23 April 2012, from http://www. capetown.gov.za/en/PublicParticipation/Documents/DPLG_Public Participation Policy_Final_ 5 July(2).pdf

South Africa. Department of Provincial and Local Government, 2008, Project Directive National Education, Training and Research Needs and Resources Analysis (NETaRNRA) for Disaster Risk Management in South Africa DPLG (T) 17/2008, viewed 15 October 2012, from http://www.ndmc.gov.za/Documents/NETaRNRAReport/ tabid/295/ctl/ViewDocument/mid/678/ItemID/142/Default.aspx

Twigg, J., 2004, Disaster risk reduction - Mitigation and preparedness in developmen and emergency programming, HPN, London, 365 p. (Good practice review, 9).

Twigg, J., 2009, Identifying partnership needs and opportunities, Disaster studies Working Paper 18, viewed 15 August 2012, from http://www.abuhc.org/ Publications/Working\%20Paper\%2018.pdf

United Nations Development Programme (UNDP), 2008, Capacity development Practice note, viewed 15 February 2016, from http://unpcdc.org/media/8651/ pn_capacity_development.pdf

United Nations Office for Disaster Risk Reduction (UNISDR), 2004a, Disaster Risk Reduction for sustainable development in Africa: Programme of action for the implementation of the Africa Strategy for Disaster Risk Reduction (2005-2010), UNISDR, Genève.

United Nations Office for Disaster Risk Reduction (UNISDR), 2004b, Living with risk: global review of disaster reduction initiatives, ISDR Secretariat, Genève, $429 \mathrm{p}$.
United Nations Office for Disaster Risk Reduction (UNISDR), 2005, Hyogo framework for action 2005-2015: Building the resilience of nations and communities to disasters, United Nations, Genève.

United Nations Office for Disaster Risk Reduction (UNISDR), 2009, Terminology, viewed 29 March 2012, from http://www.unisdr.org/we/inform/terminology

United Nations Office for Disaster Risk Reduction (UNISDR), 2010, Strategy outline for the 2010-2011 World Disaster Reduction Campaign on making cities resilient addressing urban risk, Campaign Document, UNISDR, Genève, $15 \mathrm{p}$, viewed 08 March 2011, from http://www.unisdr.org/english/campaigns/campaign2010-2011/ documents/230_CampaignStrategy.doc

Van Niekerk, D., 2005, 'A comprehensive framework for multi-sphere disaster risk reduction in South Africa', PhD thesis, North-West University.

Van Niekerk, D., 2006, 'Disaster risk management in South Africa: The function and the activity - Towards an integrated approach', Politeia 25(2), 95-115.

Van Niekerk, D., 2007, 'Local government disaster risk management', in G. Van der Waldt (ed.), Municipal management: Serving the people, pp. 227-250, Juta, Cape Town.

Van Niekerk, D., 2010, 'More rhetoric and less action? A look at the outcomes of the second ministerial conference on disaster risk reduction', Disaster Management: Southern Africa, 10-11.

Van Niekerk, D., 2011, The South African disaster risk management policy and legislation - A critique, 27 p, viewed 31 October 2013, from http://acds.co.za/ uploads/research reports/SA law_2011.pdf

Van Niekerk, D. \& Annandale, E., 2013, 'Utilising participatory research techniques for community-based disaster risk assessment', International Journal of Mass Emergencies and Disasters 31(2), 160-177.

Van Niekerk, D. \& Coetzee, C., 2012, 'African experiences in community-based disaster risk reduction', in R. Shaw (ed.), Community-based disaster risk reduction, pp. 333-349, Emerald, Bingley.

Van Riet, G. \& Diedericks, M., 2009, An investigation into the 'optimal' location of the disaster management function, within district, metropolitan and provincia government in South Africa, ACDS, Potchefstroom, $30 \mathrm{p}$

Vermaak, L. \& Van Niekerk, D., 2004, 'Disaster risk reduction initiatives in South Africa', Development South Africa 21(3), 555-574. https://doi.org/10.1080/ 0376835042000265487

Wilkinson, E., 2009, Building a 'culture of prevention': Challenges to institutionalising disaster risk reduction in local development in Mexico, viewed 20 August 2012, from http://www.abuhc.org/Publications/Working\%20Paper\%2021.pdf

World Bank, 2005, Natural disaster risk management in the Philippines: Enhancing poverty alleviation through disaster reduction, viewed 18 August 2012, from https://openknowledge.worldbank.org/bitstream/handle/10986/8748/338220R EPLACEM1asterOReport1combine.pdf?sequence $=1$ 